\title{
Integrated proteomics and histochemical analysis of Araucaria angustifolia (Bertol.) Kuntze (Araucariaceae) in embryogenic suspension culture
}

\author{
Francis Pereira-Dias', Neusa Steiner', Gabriela C. Cangahaula-Inocente', Ana Paula \\ Lando', Marisa Santos', Miguel Pedro Guerra ${ }^{1,2} \rightleftarrows$
}

Pereira-Dias F., Steiner N., Cangahaula-Inocente C.G., Lando A.P., Santos M., Guerra M.P., 2020. Integrated proteomics and histochemical analysis of Araucaria angustifolia (Bertol.) Kuntze (Araucariaceae) in embryogenic suspension culture Ann. For. Res. 63(2): 27-43.

Abstract Cell suspension culture is a useful in vitro model-system for both scaling up and conserving the Brazilian conifer Araucaria angustifolia. In the present work, cell suspension of Araucaria was subjected to proteomics, biochemical and histochemical analyses. The results revealed new insights underlying the molecular mechanism of proembryogenic masses transition in cell suspension. Embryogenic cell cultures were cultivated in a basal liquid medium modified in a Steward apparatus (orbital agitator). Cell growth dynamics was evaluated using cell volume after sedimentation, fresh weight, mitotic index, conductivity, $\mathrm{pH}$, and the number of proembryogenic masses (PEMs: I, II, III). Histochemical parameters, cell viability, and cell death analyses were performed to pinpoint growth rates. Proteomics analysis was performed using two-dimensional electrophoresis, and protein identification was carried out by MALDI-TOF-TOF tandem mass spectrometry. Cell growth dynamics showed a predominance of PEM III. Maximum slope of the exponential phase growth in fresh weight occurred at exponential phase after 15 days (optimal cultivation time), after which cell viability and $\mathrm{pH}$ decreased, thereby allowing the identification of stressrelated proteins. Several metabolism and growth proteins were abundant, such as: cytoskeletal, WOX1, cytokinin-related, and auxin-related proteins acting on cell wall modification, suspensor cell formation, and PEM I to PEM III transition.

Keywords: Brazilian pine; cell suspension; proteomics; proembryogenic masses; somatic embryogenesis.

Addresses: ${ }^{1}$ Graduate Program in Plant Genetic Resources, Plant Developmental Physiology and Genetics Laboratory, Federal University of Santa Catarina, Florianópolis, Brazil $\mid{ }^{2}$ Graduate Program in Agricultural and Natural Ecosystems, Federal University of Santa Catarina, Curitibanos, Brazil

$\circledast$ Corresponding Author: Miguel Pedro Guerra (miguel.guerra@ufsc.br).

Manuscript received June 7, 2020; revised December 18, 2020; accepted December 22, 2020. 


\section{Introduction}

Araucaria angustifolia (Bertol.) Kuntze (Araucariaceae) is a Brazilian conifer with ethnocultural, economic, ecological, historical, and pharmaceutical value. Araucarias bracts extract was shown to be an oncogene suppressor and, hence, a natural anticancer agent (Branco et al. 2019). Overexploitation of its high-quality wood has depleted Araucaria's population, leading to critically endangered status (Stefenon et al. 2007, IUCN 2017, Inza et al. 2018, Reis et al. 2018). The recalcitrant nature of Araucaria seeds hampers storage of reproductive material (Farias-Soares et al. 2013). For this reason, tissue culture has been an important plant conservation strategy (Salmen Espindola et al. 1994, Stefenon et al. 2009, Rogge-Renner et al. 2017, Inza et al. 2018).

Among the tissue culture techniques, somatic embryogenesis involves the formation of a bipolar embryo and a new plant from a single somatic cell (Von Arnold et al. 2002, Von Arnold 2008). Genetic, biochemical and hormonal reconfigurations happen during the dedifferentiation and differentiation of a somatic embryo (Fehér et al. 2003, George et al. 2008), and the underlying molecular mechanisms have been a long-standing scientific question (Vogel 2005). Somatic embryogenesis applies to the study of totipotency (Vogel 2005, Von Arnold 2008, Steiner et al. 2015), cryopreservation (Von Arnold 2008) and massive micropropagation to produce plants cheaply (Stasolla \& Yeung 2003).

Somatic embryos have been obtained using cell suspension (Steward et al. 1958), a highefficiency system for mass propagation of woody plants (Hakman \& Fowke 1987, Steiner et al. 2008, Maurer et al. 2010). Cell suspension has been employed in Pinus taeda L. (Silveira et al. 2004), Picea glauca subsp. engelmannii (Engelm.) T.M.C. Taylor, P. mariana (Mill.) Britton, Sterns \& Poggenb. (Lulsdorf et al. 1992), and P. abies (L.) H. Karst. (Von Arnold et al. 1995). Cell suspension was also applied as a study model for cell totipotency, differentiation, and dedifferentiation, as well as biochemical and physiological aspects of plant morphogenesis (Silveira et al. 2006, Steiner et al. 2008).

Previous somatic embryogenesis studies in the Brazilian conifer A. angustifolia (Maurer et al. 2010, De Oliveira et al. 2018) showed that the cell suspension system was more efficient in promoting cell growth than the cultures maintained in gelled medium. Once induced from immature zygotic embryos, somatic embryogenesis follows the phases of proliferation, prematuration, and maturation (Von Arnold 2008). In the proliferation phase, cell cultures are formed by proembryogenic masses (PEM), which divide cyclically into PEM I, II and III. Despite various attempts reported in the literature (Farias-Soares et al. 2014), a full somatic embryogenesis protocol of A. angustifolia has not yet been accomplished. According to Steiner et al. (2015), PEM III formation and polarization is a crucial step to form early somatic embryos. Thus, integrated cell biology studies are necessary to help overcome the bottlenecks observed with the somatic embryogenesis protocol (Guerra et al. 2016).

Proteins are complex molecules present in cell signaling and biochemical pathways (Heldt et al. 2011) that regularly change owing to different stimuli (Fey \& Larsen 2001). The mechanism underpinning growth and development of live cells may be characterized as a state of dynamic protein flux (Fey \& Larsen 2001, Chen \& Harmon 2006). Thus, somatic embryogenesis can be better understood by using proteomics approaches. Such studies are relevant, especially for non-sequenced species (Fey \& Larsen 2001, Rogowska-Wrzesinska et al. 2013), and the identification of proteins related to early somatic embryo formation can help define the early detection of cell lines with high embryogenic potential in A. angustifolia 
(Dos Santos et al. 2016).

The non-Pinaceae conifer database is incomplete, and $A$. angustifolia, a non-model conifer, presents little, or no, bioinformatic data (Fraga et al. 2016). Because of this, twodimensional gel electrophoresis (2-DE) is a relevant approach to prevent identification failures (Rogowska-Wrzesinska et al. 2013). Various studies have implemented twodimensional gel electrophoresis (2-DE) to compare zygotic and somatic embryogenesis in A. angustifolia (Balbuena et al. 2011, Jo et al. 2014, Elbl et al. 2015, Dos Santos et al. 2016). Proteomics analysis helps to frame important cell biology activities from the perspective of protein abundance (Rabilloud et al. 2010), bringing insight to the underlying factors involved in the transition of PEMs during the growth dynamics of $A$. angustifolia suspension cells. Here, we took advantage of this system to compare the proteomics profile of five phases of growth dynamics in association with an integrated approach toward PEMs by histochemical analysis. Our analysis revealed a subset of proteins highly abundant in the transition of PEMS, and we discuss the implications of this discovery in cellular metabolism for a scale-up system of somatic embryogenesis in this species.

\section{Materials and methods}

\section{Cell culture media and multiplication}

Female cones bearing embryos at the precotyledonary stage were collected in Lages (Santa Catarina State, southern Brazil) $\left(28^{\circ} 02^{\prime} \mathrm{S} ; 50^{\circ} 17^{\prime} \mathrm{W}\right)$ in late December. Immature zygotic embryos were used as primary explant to obtain embryogenic cultures, as proposed by Steiner et al. (2005), using growth regulatorfree medium (BM0) with BM macro-, micro-salts and vitamins (Gupta \& Pullman $1991)$, in addition to myo-inositol $\left(1.0 \mathrm{~g} \mathrm{~L}^{-1}\right)$, L-glutamine $\left(1.0 \mathrm{~g} \mathrm{~L}^{-1}\right)$, casein hydrolysate $\left(0.5 \mathrm{~g} \mathrm{~L}^{-1}\right)$. and sucrose $\left(30 \mathrm{~g} \mathrm{~L}^{-1}\right)$. The cultures were maintained in Petri dishes (100 x 15 $\mathrm{mm}$ ) containing $25 \mathrm{~mL}$ of semi-solid culture media in the dark $\left(25 \pm 2^{\circ} \mathrm{C}\right)$. Subculturing was done every three weeks. Afterward, $2 \mathrm{~g}$ of cell cultures were inoculated in $100 \mathrm{~mL}$ of the same BM0 modified medium (modified BM (MBM)) in nipple flasks on a Steward apparatus (slow orbital agitator, $1 \mathrm{rpm}$ ).

\section{The growth of cell suspension culture, $\mathrm{pH}$, and conductivity}

Two complementary methods were used to evaluate growth dynamics: invasive (fresh weight) and noninvasive (cell volume after sedimentation) (Mustafa et al. 2011). Cell volume after sedimentation was measured after 40 min of sedimentation in a vertical position, using at least four modified nipple flasks (Silveira et al. 2002). Daily measurements were done up to 50 days of cell growth $(\mathrm{N}=6)$.

Invasive analyses were carried out for each growth phase: phase zero (0), initial, exponential, linear and stationary $(\mathrm{N}=30)$. Phase zero (0) corresponds to samples in the Petri dish used to begin the cell suspension system.

Cell cultures and liquid medium were separated using a cell dissociation sieve (Sigma S4145, 80 microns). Separated liquid medium $(50 \mathrm{~mL})$ was used to measure $\mathrm{pH}$ and conductivity along the phases of cell growth dynamics. Both medium $\mathrm{pH}$ and conductivity were tested in the presence of cells and medium free of cells. At least six biological replicates were used. To better study the best time for subculturing before a salt stress situation (Barkla et al. 2009), conductivity and pH were measured, as described by Dos Santos et al. (2010).

The cell cultures were placed on absorbent paper for 4 min under a laminar hood to ensure removal of the liquid medium. Measurement of fresh weight was done using a scale (Mustafa et al. 2011). Apart from fresh weight analysis, samples collected under the same 
methodological procedure were used for biochemical, histochemical and proteomics studies, as described below.

\section{Mitotic index}

Temporary slides were made using $50 \mathrm{mg}$ of cell culture in three biological replicates. Cells were exposed to acid hydrolysis $(1: 1 \mathrm{HCl}$ and Ethanol), squashed, and then stained with $1 \%$ aceto-orcein stain. Observation was carried out under an optical microscope (Olympus BX40, Tokyo, Japan) attached to the Cellsens Dimension Software (Olympus) imaging system. The final index was derived from counting 100 cells in nine repetitions per phase (Szabados et al. 1993).

\section{Number of PEMs}

Percentages of PEM I, II and III were evaluated, according to Farias-Soares et al. (2014), to understand the dynamics of different types of PEMs during the different phases of cell growth. Three biological replicates of 200 mg (fresh weight cells) per phase were used. Observations were made using an inverted microscope (Olympus IX80, Tokyo, Japan). With the help of a counting Petri dish, nine counts of 100 cells per PEM per phase were done.

\section{Viability and cell death}

Cell viability and death were measured using the Evans Blue methodology proposed by Bozhkov et al. (2001). The UV-HALO DB20 spectrophotometer (Dynamica Scientific Ltd., Newport Pagnell) was used to measure absorbance. The absorbance value per phase was taken from an average of six biological replicates, each having three technical replicates.

\section{Histochemical features}

Histochemical tests employed double staining of Evans Blue and acetic carmin $(0.1 \% \mathrm{p} / \mathrm{v})$ to separate embryogenic from non-embryogenic cells; thionin (Kraus \& Arduin 1997) for mucilage; Lugol (Jensen 1962) for starch; Sudan III (Sass 1951) for total lipids and cutin and ruthenium red (Johansen 1940) for pectin. Temporary laminas with $50 \mathrm{mg}$ of fresh cells were prepared with at least three biological replicates for each test. Visualization was done with an optical microscope (Olympus BX 40, Tokyo, Japan) attached to the Cellsens Dimension Software (Olympus) imaging system.

\section{Protein extraction and quantification}

Six biological samples from each phase of the growth dynamics were collected $\left(0,5^{\text {th }}, 12^{\text {th }}\right.$, $19^{\text {th }}$ and $39^{\text {th }}$ day), fast-frozen in liquid nitrogen and stored at $-20{ }^{\circ} \mathrm{C}$. Extraction was performed as described by Cangahuala-Inocente et al. (2013). Briefly, samples (1.5 g) were ground to a powder with the aid of liquid nitrogen. Macerated samples were homogenized with 10 $\mathrm{mL}$ extraction buffer (50 mM Tris- $\mathrm{HCl}, \mathrm{pH} 8.5$, $5 \mathrm{mM}$ EDTA, $100 \mathrm{mM} \mathrm{KCl}, 30 \% \mathrm{w} / \mathrm{v}$ sucrose, $2 \% \beta$-mercaptoethanol, $1 \mathrm{mM}$ PMSF) and 10 $\mathrm{mL}$ of Tris buffer-saturated phenol $(\mathrm{pH} 7.8)$ by agitation for $30 \mathrm{~min}\left(4^{\circ} \mathrm{C}\right)$. After centrifugation (30 $\mathrm{min} ; 15000 \mathrm{~g} ; 4{ }^{\circ} \mathrm{C}$ ), the phenolic phase was recovered, homogenized with $5 \mathrm{~mL}$ of extraction buffer, and then recentrifuged (30 min; $15000 \mathrm{~g} ; 4^{\circ} \mathrm{C}$ ).

The phenol phase was collected, and protein was precipitated in $100 \mathrm{mM}$ of ammonium acetate in cold methanol (1:5 v/v) (12 h, -20 $\left.{ }^{\circ} \mathrm{C}\right)$. Afterward, samples were centrifuged (30 min; $15000 \mathrm{~g} ; 4^{\circ} \mathrm{C}$ ), and the pellet was washed $3 \mathrm{x}$ with methanol $(1 \mathrm{~mL})$ and acetone $(1 \mathrm{~mL})$. The dried protein pellet was diluted with 0.3 $\mathrm{mL}$ of solubilization buffer (7 M urea, $2 \mathrm{M}$ thiourea, 3\% Chaps, $1.5 \%$ DTT and 2\% IPG buffer) by mild vortexing and stored at $-20{ }^{\circ} \mathrm{C}$. 
Protein concentration was carried out according to Ramagli \& Rodriguez (1985) who made modifications to the Bradford (1976) protocol. All protein quantification was performed with a UV-HALO DB20 spectrophotometer (Dynamica Scientific Ltd., Newport Pagnell) with Bovine Serum Albumin as standard.

\section{Two-dimension gel electrophoresis (2-DE)}

Isoelectric focusing (GE Healthcare) was carried out using strips (13 cm, $\mathrm{pH} 3-10)$. Strips containing $350 \mu \mathrm{g}$ of proteins were rehydrated with $0.25 \mathrm{~mL}$ of buffer (7 M Urea, $2 \mathrm{M}$ Thiourea, 2\% CHAPS, $0.2 \%$ DTT, 2\% IPG buffer and $0.002 \%$ bromophenol blue) for $12 \mathrm{~h}$. Focusing was done on an isoelectric focusing unit (Ettan IPGphor 3 IEF system, GE Healthcare). Afterwards, strips were equilibrated for $20 \mathrm{~min}$ in an equilibrium solution $(50 \mathrm{mM}$ Tris- $\mathrm{HCl}, \mathrm{pH} 8.8,6 \mathrm{M}$ urea, $30 \%$ glycerol, $2 \%$ SDS, $0.002 \%$ bromophenol blue) containing 1\% DTT and an additional 20 min in the equilibrium buffer containing 2.5\% $(\mathrm{w} / \mathrm{v})$ iodoacetamide.

For 2-DE analysis, SDS gels with 12\% polyacrylamide were run in the Hoefer SE 600 Ruby System (GE Healthcare) at $10 \mathrm{~mA} / \mathrm{gel}$ (1 h), $20 \mathrm{~mA} / \mathrm{gel}(1 \mathrm{~h})$, and $30 \mathrm{~mA} / \mathrm{gel}$. Precision Plus Protein ${ }^{\mathrm{TM}}$ Dual Color Standards 10-250 $\mathrm{kD}$ system (Bio-Rad) was used. For each phase, six 2-DE gels were made from six independent protein extractions. The gels were stained with staining solution (1\% Coomassie blue G-250, $2 \%$ phosphoric acid, $8 \%$ ammonium sulfate and 20\% methanol) according to Mathesius et al. (2001), followed by storage in $1 \%$ acetic acid $\left(4^{\circ} \mathrm{C}\right)$.

Gels were scanned with ImageScanner ${ }^{\circledR}$ (GE Healthcare) and analyzed with ImageMaster 2D Platinum ${ }^{\circledR}$ software (v.7.0). Spot detection was done using the following parameters: smooth (95), minimum area (70), and saliency (15). Protein abundance was estimated by volume percentage $(\% \mathrm{vol})$. To be sampled spots should be present in at least three or more biological replicates. Extraction aimed to identify differential and unique expression. Reproducible selected spots for mass spectrometry characterization (i) were expressed differentially between biological replicates, (ii) displayed fold change \pm 2 , (iii) had $\mathrm{a} \% \mathrm{vol}>0.2$, and (iv) were significant statistically by the Student's $t$-test $(\mathrm{p}<0.05)$.

\section{Trypsin digestion and protein identification}

Protein digestion was performed according to Cangahuala-Inocente et al. (2013). The selected spots were manually cut, destained (1.5 mL with $50 \%$ Acetonitrile and $25 \mathrm{mM}$ Ammonium Bicarbonate) and dried $(0.1 \mathrm{~mL}$ of 100\% Acetonitrile).

Proteins inside spots were digested with porcine trypsin $\left(20 \mathrm{ng} / \mathrm{mL}, 12 \mathrm{~h}, 37^{\circ} \mathrm{C}\right)$, and the peptides were recovered by vortexing the gels $(30 \mathrm{~min})$ with extraction solution $(0.1 \mathrm{~mL}$ 50\% Acetonitrile, 5\% TFA). Finally, peptides were dried and concentrated using SpeedVac. For spectrometric analysis, the peptides were solubilized in $0.1 \%$ trifluoroacetic acid. A sample mixed in a 1:1 recrystallized HCCA matrix (Bruker Daltonics) was spotted on a 384-MPT AnchorChip plate. The mass spectrometric analysis and the mass profiles of the peptides were performed using the Maldi Autoflex III smart beam TOF/TOF (Bruker Daltonics). Matrix-assisted laser desorption/ ionization mass spectra acquiring conditions were the same as those used by Rockenbach et al. (2015). Identification of the proteins took into account carbamidomethylation of cysteines and peptide mass tolerance 100 ppm, and $\mathrm{MS} / \mathrm{MS}$ tolerance of $0.5 \mathrm{Da}$. All proteins were identified with MASCOT score $(\mathrm{p}<0.05)$ (http://www.matrixscience.com/), as searched against SwissProt (Viridiplantae Databank). The molecular and cellular functions were characterized by Gene Ontology by searching the protein knowledgebase UniProtKB Database (http://www.uniprot.org/). 


\section{Results}

\section{Growth dynamics}

Cell volume after sedimentation showed four phases: initial $\left(0-8^{\text {th }}\right.$ day), exponential $\left(9^{\text {th }}-15^{\text {th }}\right.$ day), linear $\left(16^{\text {th }}-23^{\text {rd }}\right.$ day $)$ and stationary $\left(24^{\text {th }}\right.$ $50^{\text {th }}$ day) (Fig. 1A). Mitosis was observed in all of the phases of cell growth (Figs. 1B-G). Higher cell division rates were observed in initial-linear phases of the cell growth curve. However, the stationary phase showed the lowest value of mitotic index, indicating a smaller number of dividing cells and, hence, a constant value for fresh weight was found for this phase of the growth dynamics (Table 1). Proliferation and growth were highly stimulated to the point that we observed a $139 \%$ increase in fresh weight $(7.89 \pm 2.09 \mathrm{~g})$ in 15 days, the highest of all phases (Table 1).

Independent of growth dynamics phases, a higher number of PEM III was observed (Figs. 2A, B). The number of PEM II was highest at exponential phase (Figs. 2A, C), and PEM I was highest at the linear phase (Figs. 2A, D). The lowest number of PEM I occurred at the stationary and initial phases (Fig. 2A, D). For the first time, red ruthenium staining allowed us to identify the presence of pectin substances in the suspensor cells (SC) and embryogenic tube cell (Figs. 2E-F) with stronger staining when compared to the embryogenic cells (EC) (Figs. 2E-F). Evans blue assay indicated nonviable cells in all phases (Fig. 3A); however, over time, the mean value of absorbance increased, becoming highest at the stationary phase, suggesting that the cell death program occurs over time, especially at the stationary phase (Fig. 3A). The exponential phase showed cells with more viability than that in the linear phase (Fig. 3A).

The $\mathrm{pH}$ value of $5.8( \pm 0.10)$ and the conductivity $(3.07 \pm 0.02)$ in the cell-free medium were constant (Fig. 3B), but in the medium with cells, the $\mathrm{pH}$ value became more acidic through time. Conductivity in medium with cells oscillated during all phases (Fig. 3B). The lowest $\mathrm{pH}$ and conductivity values were observed in the linear phase.
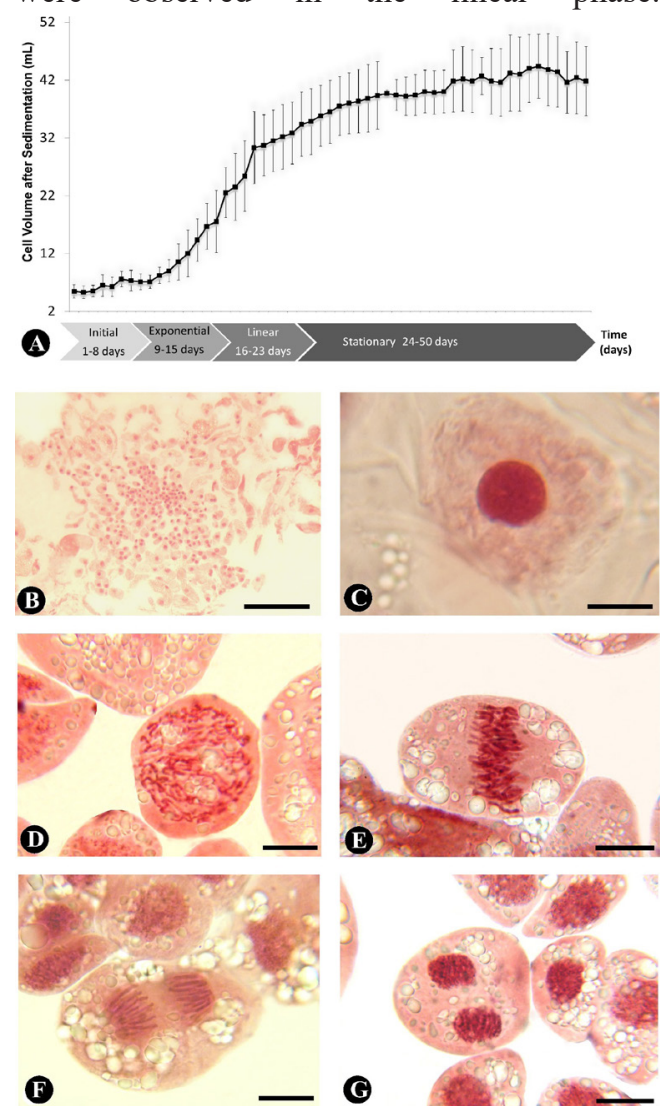

Figure 1 A: Growth dynamics of Araucaria angustifolia shows the cell volume after sedimentation and the phases of growth dynamics. B: Mitotic index. C: Detail of a cell in interphase. D: Prophase cell; chromosomes can be observed. E: Metaphase cell. Chromosomes are present in the equatorial plate. F: Anaphase cell. G: Telophase cells. Scale bar: $A=100 \mu \mathrm{M}$; $\mathrm{B}-\mathrm{F}=20 \mu \mathrm{M}$

\section{Proteins}

Total protein concentration (mg. $\mathrm{g}^{-1}$ ) decreased from the initial to the stationary phase (Fig. 3C). The linear phase presented a higher number of total and unique spots. A total of 75 were identified from their peptide mass fingerprint, as indicated in Figure 4 and Table S1. Based 
on UniProt KB database classification, the predominant subcellular location is cytoplasm (34), followed by chloroplast (11) and nucleus(6) (Fig. 5A). According to predicted biological process (Bevan et al. 1998) and the UniProt KB database, the preeminent functions were metabolism, growth/division,


Figure 2 A: Number of PEMs relative to analyzed phases of cell growth dynamics. Values expressed in percentage. B-D: Double coloration by Evans blue and acetic carmine histochemical test in Araucaria angustifolia. Differential coloration shows embryogenic cells (EC) in red and suspensor cells (SC) in blue. B: Proembryonic mass III (PEM III); a great number of suspensor cells. C: Proembryonic mass II (PEM II). D: Proembryonic mass I (PEM I); a small number of embryogenic cells and suspensor cells. E-G: Histochemical analysis of $A$. angustifolia submitted to red ruthenium staining; suspensor cells showed a positive reaction indicating the presence of mucilage and pectin. E: Proembryonic mass III (PEM III); F: Proembryonic mass II (PEM II); G: Proembryonic mass I (PEM I). Scale bar: B, E, $\mathrm{F}=200 \mu \mathrm{M} ; \mathrm{C}: 150 \mu \mathrm{M} ; \mathrm{D}, \mathrm{G}=100 \mu \mathrm{M}$.
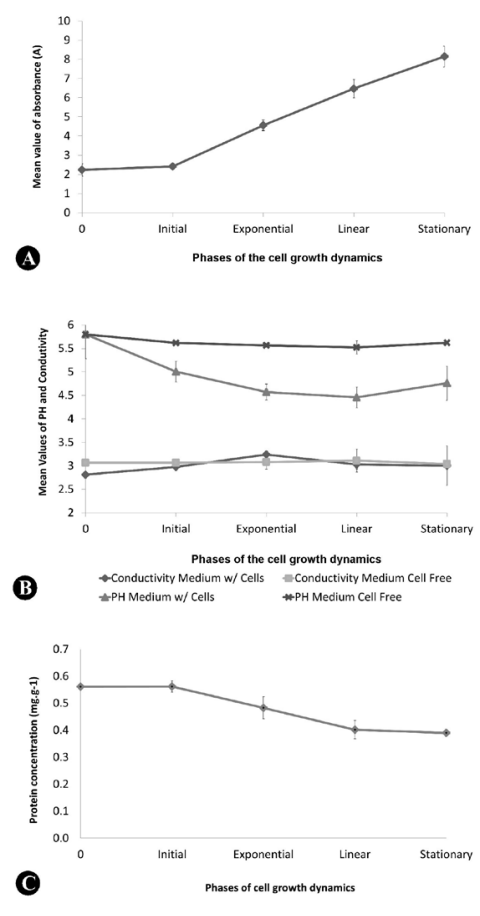

Figure 3 A: Cell death and non-viability, as determined by Evans Blue assay, during various phases of cell growth dynamics of Arancaria angustifolia. Values are mean \pm standard deviation of the measured absorbance; $\mathrm{n}=$ six biological replicates and three technical replicates. B: Mean values of $\mathrm{pH}$ and conductivity during the various phases of cell growth dynamics of A. angustifolia. Graphic shows two analyzed situations, one with and the other without the presence of cells in the medium (cell-free medium). C: Protein concentration during the various phases of cell growth dynamics of $A$. angustifolia. 


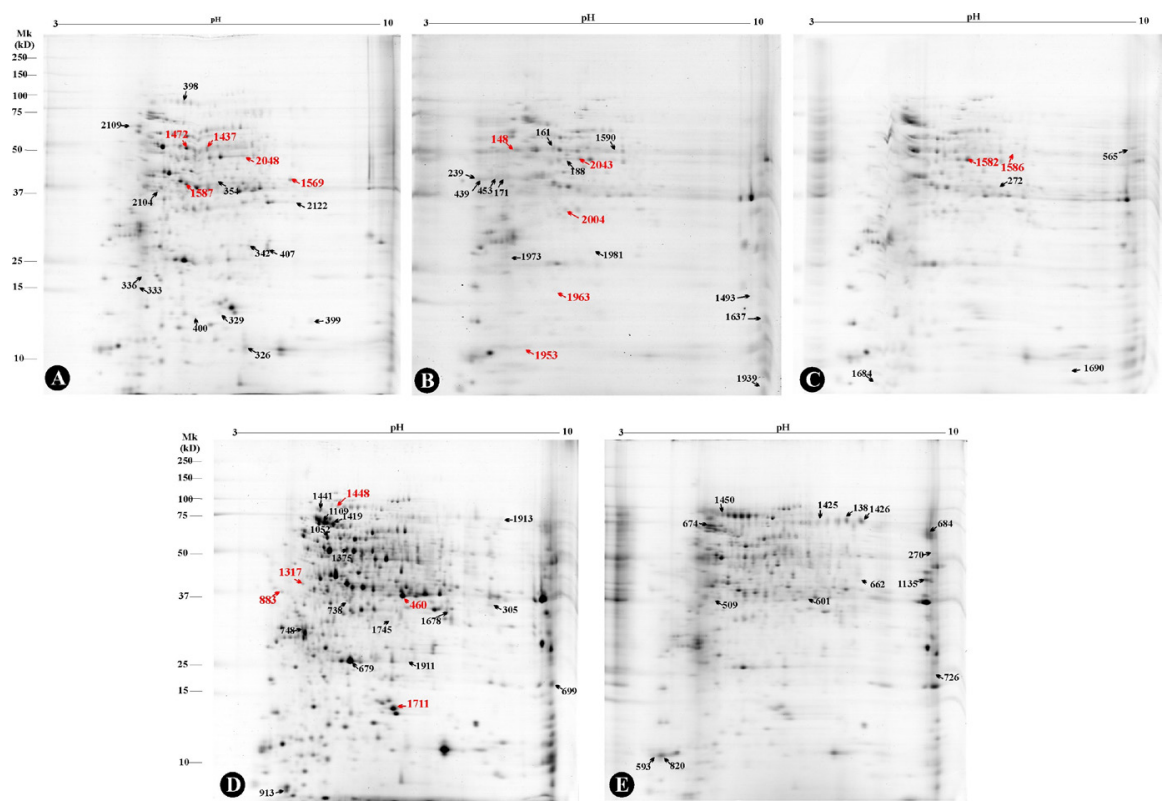

Figure 4 2-DE gels of phase 0 (A), initial (B), exponential (C), linear (D) and stationary (E) of Araucaria angustifolia under a cell suspension system. The identified proteins are marked with numbers and arrows following Table S1; red arrows indicate that the 17 identified proteins were differentially expressed and were present in all phases
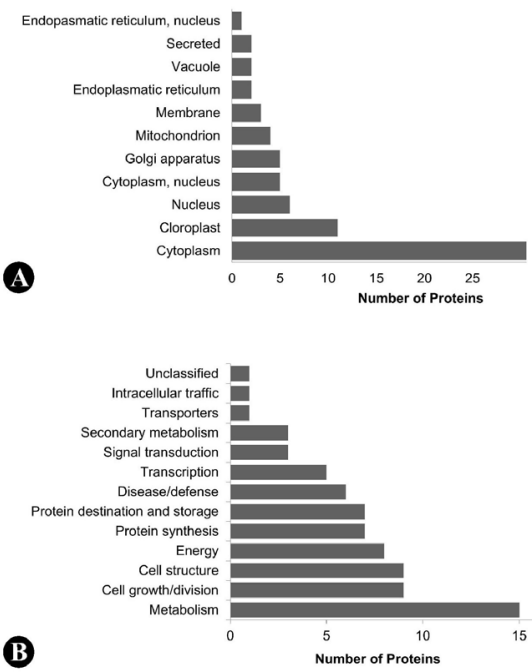

Figure 5 A: Histogram of the subcellular localization of the identified proteins in Araucaria angustifolia embryogenic cultures under cell suspension based on gene ontology annotation terms. B: Histogram of the functional classification of $A$. angustifolia proteins in embryogenic cultures under cell suspension system.
Among the metabolic pathways are photosynthesis (Spot 1437) and glycolysis (Spot 2043, Spot 1582). Other proteins interacted with major hormone pathways, such as auxin (F-box - Spot 1448; auxinrepressed proteins - Spot 1586) and cytokinin (probable cytokinin riboside 5'-monophosphate phosphoribohydrolase - Spot 2004).

We also identified cell growth/division proteins, such as WUSCHEL-related homeobox 1 (Spot 1690), action-related proteins (Spots 439, 453, 171, and 239), profilin-2 (Spot 913), and tubulin- $\beta 2$ chain (Spot 148) (Fig. 5B, Table S1).

A total of 31 proteins were exclusive to a unique single phase. Among the exclusive proteins, heat shock proteins (Spot 1109) were found to be exclusive to the stationary phase, indicating cell stress (Table S1). 


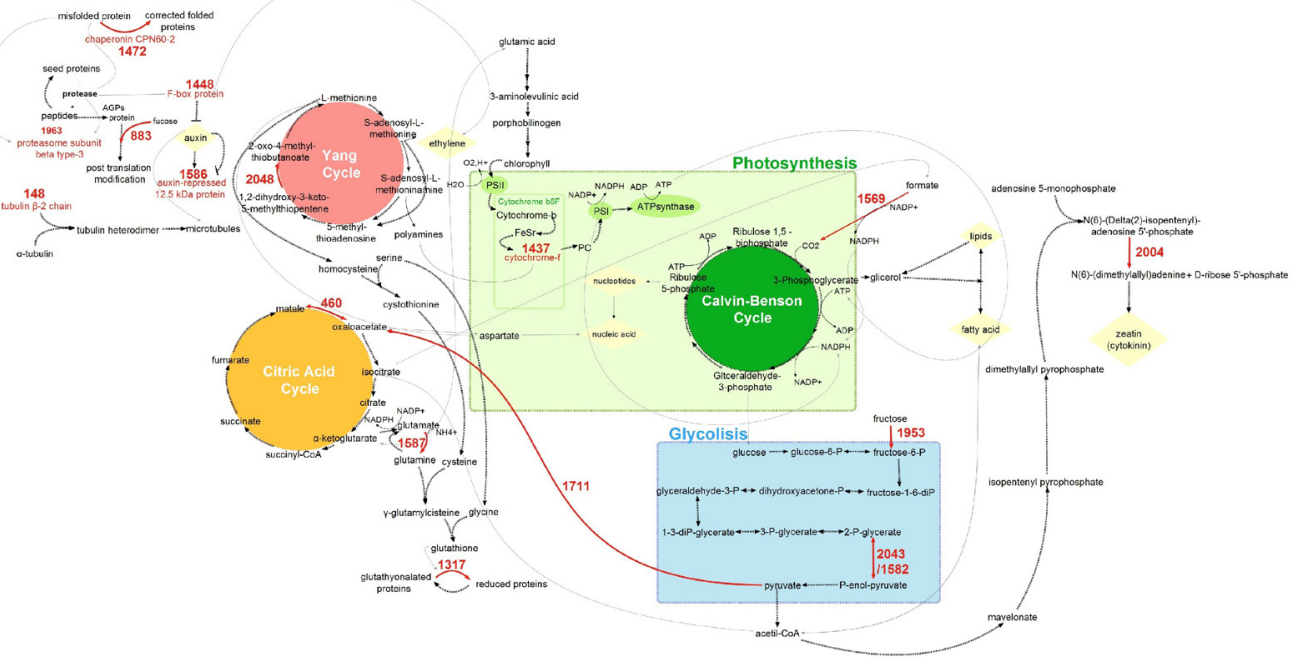

Figure 6 Mind map of differentially expressed proteins present in all phases of the cell growth dynamics of Araucaria angustifolia. Among the various interacting pathways, the mind map shows the most significant metabolic pathways in which these proteins play a role. Gray arrows indicate possible pathways connecting one protein to another, while dotted arrows show indirect pathways, straight arrows show direct pathways, and red arrows show the action of an identified protein. *Protein numbers follow Table S1. ** The metabolic pathways were described by UniProtKB Database; Buchanan et al. (2000)

Table 1 Fresh weight and mitotical index increment per phase under cell suspension system

\begin{tabular}{lrrrr}
\hline Phases & Time (days) & $\begin{array}{r}\text { Average Fresh } \\
\text { Weight (g) }\end{array}$ & Increment & Mitotic Index \\
\hline 0 & 0 & 2.00 & & \\
Initial & $0-8^{\text {th }}$ & $3.30 \pm 0.31$ & $65 \%$ & $3 \%$ \\
Exponential & $9^{\text {th }}-15^{\text {th }}$ & $7.89 \pm 2.09$ & $139 \%$ & $1 \%$ \\
Linear & $16^{\text {th }}-23^{\text {rd }}$ & $11.70 \pm 1.67$ & $48 \%$ & $1 \%$ \\
Stationary & $24^{\text {th }}-50^{\text {th }}$ & $17.82 \pm 3.14$ & $52 \%$ & $0 \%$ \\
\hline
\end{tabular}

\section{Discussion}

\section{Cell suspension growth dynamics: cells enter stress after 15 days of cultivation}

Our results pointed out that Araucaria cell growth under cell suspension resulted from simultaneous increases of PEM I and PEM II (Fig. 2A, C-D), in addition to higher mitosis rate (Fig. 1B-G, Table 1), and, hence, fresh weight (Fig. 1A), as observed during the exponential phase. PEMs consist of homogeneous clusters of $\mathrm{EC}$ and $\mathrm{SC}$ without polarity and mainly formed by primary cell walls (Fraga et al. 2015). In these cells, red ruthenium stain indicates the presence of pectic substances and mucilage (Fig. 2E-G). Pectins are galacturonic acid (GalA)-containing polysaccharides (Muschitz et al. 2015), and, together with some proteins, they are responsible for interactions between the cell walls of neighbouring cells (Bou Daher \& Braybrook 2015). It is well known that intensified polymer synthesis during cell suspension culture helps to maintain cell adhesion contacts and prevent aggregate destruction such as that observed 
in Lupinus polyphyllus, Pyrus communis and Arabidopsis thaliana (Wink 1994, Jamet et al. 2006, Webster et al. 2008). Knox (1992) found that cells lacking pectin separated themselves from the tissue. Moreover, Maurer et al. (2010) report the secretion of arabinogalactans in a cell suspension of $A$. angustifolia which according to Darjania (2002) it was associated with cell adhesion and cell wall changes during plant growth and development. Considering these findings and the previously description of Araucaria PEMs transition (Steiner et al. 2015) ours results indicate that pectic substances keep ECs and SCs attached to each other allowing small aggregates become large clusters of proembryogenic masses.

Apart from to play a role on maintenance of cells aggregates, polysaccharides and proteins are cell-excreted to the culture medium and modify the $\mathrm{pH}$ and conductivity value in tobacco cell suspension (Issawi et al. 2017). A similar case can be observed in our work (Fig. 3B) where the $\mathrm{pH}$ and conductivity values change in the presence of cells. Sucrose uptake and ammonium assimilation also led to acidification of culture media suspension in Lupinus polyphyllus (Wink 1994) and Ocotea catharinensis (Moser et al. 2004), suggesting a similar situation for $A$. angustifolia suspension cells. Together with this occurs the depletion of culture medium nutrient and our findings indicate that $A$. angustifolia was undergoing stress after 20 days in culture (linear phase) since the increase of formation of suspensor accomplished by cell death occurs at this phase. Therefore, we suggest that subcultures should be set at a maximum of 15 days once highest amount of cell growth and viability occurred at this time point as indicated by Evans Blue stain (Fig. 3A) and cell growth dynamics (Fig. 3B). However, in this species researchers have yet no final consensus regarding subcultivation time since FariasSoares et al. (2014) subcultivated every 15 days, while Vieira (2011) and Fraga et al. (2015) subcultivated at 20-21 days.
Our results indicated nine proteins related to growth (Fig. 5B), including actin-related proteins (Spots 439, 453, 171, 239), profilin-2 (Spot 913) and tubulin- $\beta 2$ chain (Spot 148) (Figs. 4, 5B, 6). The actin family comprised the most abundant proteins. These are structurally scaffolded proteins responsible for cell morphology, tension support, intracellular vesicular transport, attachment, adhesion properties, movement and cell cycle progression (Hussey et al. 2006, Heng \& Koh 2010). Therefore, the maximum slope of the exponential phase of cell proliferation at 15 days (Fig. 1A) may result from cytoskeletal components since the disturbance of actin filament structure and function causes the loss of cell growth and division (Heng \& Koh 2010). The higher abundance of actions in the initial phase is associated with adhesion, attachment of cells under agitation, as well as the change in cell culture conditions from solid (phase 0) to liquid medium. Such variations in the proteomic profile emphasize the importance of choosing the appropriate cultivation strategy to obtain a scale-up system of PEM III transition. The high abundance of actin and the presence of pectins/mucilage provide a safety net of cell attachment/adhesion, which is crucial to keep PEM aggregates under agitation. Similar to actin, the abundance of tubulin- $\beta 2$ chain was present in all phases (Table S1 and Fig. 6), albeit higher in the initial phase. The tubulin- $\beta 2$ chain and tubulin- $\alpha$ chain form a microtubule heteropolymer which is a cytoskeletal cell component involved in motility, morphology (Oppenheimer et al. 1988, Cai 2010), mitosis, deposition of cell wall polymers, and vesicular transportation (Llyod \& Chan 2008). Comparing the mitotic index (Figs. 1B$G)$ with the abundance of tubulin- $\beta 2$ chain, the highest abundance of tubulin- $\beta 2$ chain occurred during the same phase as the highest mitotic index. This strong interaction suggests that the tubulin- $\beta 2$ chain coordinates mitosis, allowing correct chromosomal division.

Another identified protein related to cell 
growth was profilin-2, an evolutionarily conserved G-actin-binding protein responsible for controlling growth (Carlsson et al. 1977, Hussey et al. 2006, Benzanilla et al. 2015) and preventing spontaneous nucleation or chaotic polymerization (Hussey et al. 2006, Benzanilla et al. 2015). Because of this, profilins play a significant role in such processes as cell division, movement, elongation, shape maintenance, pollen tube and root hair growth (Radauer \& Hoffmann-Sommergruber 2007). In the present work, the abundance of profilin-2 exclusively in the linear phase could be related to the growth of suspensor cells. The analysis of the number of PEMs and their types along the growth dynamics has demonstrated an increase in the number of PEM III at the linear phase compared to the stationary phase and a decrease in the number of PEM II. Our findings are consistent with the transition and formation of PEM III from existing PEM II which can be directly attributed to the increase in suspensor cells. Chau et al. (2002) observed that overproduction of profilin increased cell elongation, while underproduction decreased it. Considering this, we may suggest that the presence of profilin-2, as one of the players involved in the elongation of embryogenic tube cells, results in the formation of suspensor cells, as shown in detail by Steiner et al. (2015). Thus, the higher number of PEM III and higher abundance of profilin-2 at the linear phase of A. angustifolia cell growth dynamics could be, at least in part, explained by the suspensor cell formation process.

\section{Proteins involved in embryogenesis metabolism and other relevant processes}

Most proteins identified were involved in cellular metabolism (20\%), among which $44 \%$ of the metabolism-related proteins were expressed in all phases, as shown in Figures $5 \mathrm{~B}$ and 6 . Among these proteins is enolase, a metalloenzyme that catalyzes the conversion of 2-phosphoglycerate (2-PG) to phosphoenolpyruvate (PEP), which is the ninth and next to the last step of glycolysis (Straeten et al. 1991), as shown in Figure 6. Enolase is a multifunctional regulatory protein with a role in sensing stress conditions (Barkla et al. 2009) like dehydration (Straeten et al. 1991). According to Balbuena et al. (2009), enolases are expressed in the zygotic embryo of $A$. angustifolia under stress conditions. In the present work, two enolases were observed: enolase I (Spot 2043) and enolase II (Spot 1582) (Fig. 6). Both proteins show the same pattern, a constant higher abundance from phase 0 to linear phase and a decrease of abundance at the stationary level (Table S1 and Fig. 6). In this cell suspension system, the carbon sources were not continuously supplied; therefore, over time, the available carbon sources decreased, and the corresponding lower rate of glucose could have decreased enolase abundance.

In our work, two auxin-related proteins were identified: F-box (Spots 333, 1448, 1973) and auxin-repressed proteins (Spot 1586) (Fig. 4). High auxin levels induce the abundance of F-box and auxin-repressed proteins that target transcription repressors by ubiquitination, inducing auxin-related genes (Buchanan et al. 2000, Somers \& Fujiwara 2009, Shi et al. 2013, Pozo \& Manzano 2014). Auxinrepressed protein genes are essential for plant growth, embryo and fruit development. The F-box proteins are involved in circadian clock, cell cycle and hormonal control (Santer \& Estelle 2009, Somers \& Fujiwara 2009, Pozo \& Manzano 2014). In A. angustifolia, the increase of indole-3-acetic acid (IAA) endogenous auxin resulted in enhanced growth of embryogenic cultures in solid medium (Steiner et al. 2007). High auxin levels induce the abundance of F-box and auxin-repressed proteins (Buchanan et al. 2000, Somers \& Fujiwara 2009, Shi et al. 2013, Pozo \& Manzano 2014). In the present work, the abundance of these proteins increased over time, suggesting a similar pattern for auxin (Fig. $6)$. Thus, auxin and auxin regulatory proteins 
play a role in the transition of PEMs, as well as the growth dynamics of cell suspension. Moreover, in plant embryogenesis, auxin acts as a morphological organizer (apical-basal axis) (Larsson et al. 2008) and regulator of polar transport (Abrahamsson et al. 2012). The high abundance of auxin is associated with initial phases of development of $A$. angustifolia zygotic embryogenesis (Pieruzzi et al. 2011). In $A$. angustifolia, auxin proteins, such as PINlike proteins, were also found in the analysis of non-embryogenic vs. embryogenic cultures (Fraga et al. 2016). The tight control of auxin and other interacting proteins in an extensive network seems to be relevant to the transition of PEMs in cell suspension and provide clues to understanding the bottleneck of PEM III-toearly embryo transition in this species (Steiner et al. 2015). In addition to auxin, we identified a probable cytokinin, riboside 5'-monophosphate phosphoribohydrolase (LOG) (Table S1 and Fig. 6 (Spot 2004)). The decreased abundance of LOG at the stationary phase is related to fresh weight constant values (Fig. 1A) and low rate of mitosis (Fig. 1B-G), pointing to the absence of growth in the stationary phase. LOG is involved in cell growth and participates in cytokinin biosynthesis by releasing an active cytokinin (Kurakawa et al. 2007, Kuroha et al. 2009, Mortier et al. 2014). Cytokinins increase cell division rates in embryos (Mortier et al. 2014), inducing the cells to enter mitosis to promote cell growth.

WUSCHEL-related homeobox 1 (WOX1) (Spot 1690) had an enhanced abundance at the exponential phase (Table S1). To the best of our knowledge, WOX1 has not been reported in previous studies with Araucaria proteomics (Balbuena 2009, Balbuena et al. 2009, 2011, De Oliveira et al. 2018). The WUSCHEL homeobox (WUS) family is responsible for maintaining shoot/root apical meristem domain, forming vegetative and floral organs, and developing the ovule (Lian et al. 2014). This family of proteins is clustered into three groups. WOX1 belongs to the same cluster as
WUS, WOX2, WOX4, WOX3, and WOX6 (Palovaara \& Hakman 2008). WOX1 acts in lateral organ formation (Van der Graaff et al. 2009), tissue-specific programming and embryonic patterning formation (Haecker et al. 2004). In heart/torpedo stage embryos of Arabidopsis thaliana, WOX1 expression was observed in the vascular primordia of cotyledons (Haecker et al. 2004). Despite this, the identification of orthologue sequences in conifers remains challenging because of the experimental difficulties (Hedman et al. 2013). For A. angustifolia, WOX1 expression in the exponential phase indicates the initiation of a tissue-specific program, as suggested by Haecker et al. (2004). Hedman et al. (2013) found a specific expression of some WUSCHEL-related homeobox proteins to embryogenic masses and late embryos in $P$. abies. The redundant action of WOX1 and WOX2 (Van der Graaff et al. 2009), which belong to the same cluster (Palovaara \& Hakman 2008), suggest that WOX 1 may act with WOX2 on somatic embryogenesis of Araucaria to initiate a tissue-specific program. Dos Santos et al. (2016) identified SERK proteins, and Steiner et al. (2012) identified SERK gene expression in Araucaria PEMs. WUSHEL expression induces LEC1 and LEC2 which act in SERK. The interaction of these proteins has been shown to modulate auxin expression to promote somatic embryogenesis in Arabidopsis thaliana and Adiantum capillusveneris ( $\mathrm{Li}$ et al. 2017). The abundance of auxin regulation proteins, together with the higher abundance of WOX1, could indicate that auxin and WUSHEL coordinate in the development of PEMs.

Finally, Figure S1 illustrates the key findings of the present work. We were able to find proteins related to cell growth/adhesion, auxin/ cytokinin-related proteins and cytoskeletal proteins expressed throughout all phases of cell suspension growth, as well as their presence in mucilage and pectin substances in cells of PEMs. We reported WUSHEL-related 
homeobox 1 in Araucaria cultures, and stressrelated proteins and cell death features were shown to be present in linear and stationary phases (Fig. S1). Our results also showed that A. angustifolia cells in suspension culture have their maximum slope of the exponential phase 15 days during, indicating that this is the best phase for subculture (Fig. S1). Taken together, the features herein evaluated improve our understanding of the scale-up system of cell suspension in Araucaria. Our findings not only define the transition of PEMs in cell suspension culture, but also connect this to the regulation of protein and cellular metabolism and corroborate to the understanding that biology studies are necessary to help overcome the bottlenecks somatic embryogenesis protocol. Further functional studies should consider our findings regarding LOG proteins and WOX 1 together with PIN-like proteins, as protein candidates in the mechanism of cell organization that leads to the PEM III-to-early embryo transition.

\section{Acknowledgements}

We thank CEBIME/UFSC. Financial support was provided by $\mathrm{CNPq}$ (National Council for Scientific and Technological Development, Proc. No 478393/2013-0, 306126/2013-3, and 311156/2017-7), FAPESC (Research and Innovation Foundation of Santa Catarina State, Proc. No 2780/2012-4). This study was financed in part by the Coordenação de Aperfeiçoamento de Pessoal de Nível Superior - Brasil (CAPES) - Finance Code 001. Thanks also are due to the Web BIOALI-CYTED.

\section{References}

Abrahamsson M., Valladares S., Larsson E., Clapham D., von Arnold S., 2012. Patterning during somatic embryogenesis in Scots pine in relation to polar auxin transport and programmed cell death. Plant Cell Tissue, Organ and Culture 109: 391-400. https://doi. org/10.1007/s11240-011-0103-8.

Balbuena T.S., 2009. Proteômica do desenvolvimento da semente de Araucaria angustifolia, Instituto de
Biociências, Universidade de São Paulo, São Paulo, $102 \mathrm{p}$.

Balbuena T.S., Jo L., Pieruzzi F.P., Dias L.L.C., Silveira V., Santa-Catarina C., Junqueira M., Thelen J.J., Schevchenki A., Floh E.S.I., 2011. Differential proteome analysis of mature and germinated embryos of Araucaria angustifolia. Phytochemistry 72: 302-311. https://doi.org/10.1016/j.phytochem.2010.12.007.

Balbuena T.S., SIlveira E.R., Junqueira M., Dias L.L.C., Santa-Catarina C., Shevchenko A., Floh E.S.I., 2009. Changes in the 2-DE protein profile during zygotic embryogenesis in the Brazilian pine (Araucaria angustifolia). Journal of Proteomics 72: 337-352. https://doi.org/10.1016/j.jprot.2009.01.011.

Barkla B.J., Vera-Estrella R., Hernández-Coronado M., Pantoja O., 2009. Quantitative proteomics of the tonoplast reveals a role for glycolytic enzymes in salt tolerance. The Plant Cell 21: 4044-4058. https://doi. org/10.1105/tpc.109.069211.

Benzanilla M., Gladfelter A.S., Kovar D.R., Lee W.L., 2015. Cytoskeletal dynamics: a view from the membrane. The Jounal of Cell Biology 209: 329-337. https://doi.org/10.1083/jcb.201502062.

Bevan M., Bancroft I., Bent E., Love K., Goodman H., Dean C., Bergkamp R., Chalwatzis N., 1998. Analysis of $1.9 \mathrm{Mb}$ of contiguous sequence from chromosome 4 of Arabidopsis thaliana. Nature 391: 485-488. https:// doi.org/10.1038/35140.

Bou Daher F., Braybrook S.A., 2015. How to let go: pectin and plant cell adhesion. Frontiers in Plant Science 6: 5-23. https://doi.org/10.3389/fpls.2015.00523.

Bozhkov P.V., Filanova L.H., von Arnold S., 2001. A key development switch during Norway spruce somatic embryogenesis is induced by withdrawl of growth regulators and is associated with cell death and extracellular acidification. Biotechnology and bioengineering 77: 658-667. https://doi.org/10.1002/ bit. 10228 .

Bradford M.M., 1976. A rapid and sensitive method for the quantification of microgram quantities of proteins utilizing the principle of protein-dye binding. Analytical Biochemistry 71: 248-256. https://doi.org/10.1006/ abio.1976.9999.

Branco C.S., Doung A., Machado A.K., Scola G., Andreazza A.C., Salvador M., 2019. Modulation of mitochondrial and epigenetic targets by polyphenolsrich extract from Araucaria angustifolia in larynx carcinoma. Anti-cancer Agents in Medicinal Chemistry 19: 130-139. https://doi.org/10.2174/18715206186661 80816142821 .

Buchanan B.B., Gruissem W., Jones R.L., 2000. Biochemistry and molecular biology of plants. American Society of Plant Physiology, Maryland, 1367 p.

Cai G., 2010. Assembly and disassembly of plant microtubules: tubulin modifications and binding to MAPs. Journal of Experimental Botany 61: 623-626. https://doi.org/10.1093/jxb/erp395. 
Cangahuala-Inocente G.C., Amaral F.P.d., Faleiro A.C., Huergo L.F., Arisi A.C.M., 2013. Identification of six differentially accumulated proteins of Zea mays seedlings (DKB240 variety) inoculated with Azospirillum brasilense strain FP2. European Journal of Soil Biology 58: 45-50. https://doi.org/10.1016/j. ejsobi.2013.06.002 46.

Carlsson L., Nyström L.-E., Sundkvist I., Markey F., Lindberg U., 1977. Actin polymerizability is influenced by profilin, a low molecular weight protein in nonmuscle cells. Journal of Molecular Biology 115: 465483. https://doi.org/10.1016/0022-2836(77)90166-8.

Chau N.-H., Ramachandran S., Molager H.E., Hedehusene C., 2002. Alteration of plant morphology by control of profilin expression. In: Patent US (ed). Institute of Molecular Agrobiology, US pp. 1-10.

Chen S., Harmon A.C., 2006. Advances in plant proteomics. Proteomics 6: 5504-5516. https://doi. org/10.3389/fpls.2015.00209.

De Oliveira L.F., Navarro B.V., Cerruti G., Elbl P., Minocha R., Minocha S.C., Dos Santos A.L.W., Floh E.S.I., 2018. Polyamines and amino acid related metabolism: the roles of argenine and ornithine are associated with embryogenic potential. Plant Cell Physiology 9(5): 1084-1098. https://doi.org/10.1093/pcp/pcy049.

Dos Santos A.L.W., Elbl P., Navarro B.V., Oliveira L.F., Salvato F., Balbuena T.S., Floh E.S.I., 2016. Quantitative proteomic analysis of Araucaria angustifolia (Bertol.) Kuntze cell lines with contrasting embryogenic potential. Proteomics 130: 180-189. https://doi.org/10.1016/j.jprot.2015.09.027.

Dos Santos A.L.W., Silveira V., Steiner N., Maraschin M., Guerra M.P., 2010. Biochemical and morphological changes during the growth kinectics of Araucaria angustifolia suspension cultures. Brazilian Archives of Biology and Technology 53: 497-504. https://doi. org/10.1590/S1516-89132010000300001.

Elbl P., Lira B.S., Andrade S.C.S., Jo L., dos Santos A.L.W., Coutinho L.L., Floh E.S.I., Rossi M., 2015. Comparative transcriptome analysis of early somatic embryo formation and seed development in Brazilian pine, Araucaria angustifolia (Bertol.) Kuntze. Plant Cell Tissue, Organ and Culture 120: 903-915. https:// doi.org/10.1016/j.jprot.2014.01.007.

Farias-Soares F.L., Burrieza H.P., Steiner N., Maldonado S., Guerra M.P., 2013. Immunoanalysis of dehydrins in Araucaria angustifolia embryos. Protoplasma 250: 911-918. https://doi.org/10.1007/s00709-012-0474-7.

Farias-Soares F.L., Steiner N., Schmidt E.C., Pereira M.L.T., Rogge-Renner G.D., Bouzon Z.L., Floh E.S.I., Guerra M.P., 2014. The transition of proembryogenic masses to somatic embryos in Araucaria angustifolia (Bertol.) Kuntze is related to the endogenous contents of IAA, ABA and polyamines. Acta Physiologiae Plantarum 36: 1853-1865. https://doi.org/10.1007/ s11738-014-1560-6.

Fehér A., Pasternak T.P., Dutis D., 2003. Transition of somatic plant cells to an embryogenic state. Plant Cell,
Tissue Organ and Culture 74: 201-228. https://doi. org/10.1023/A:1024033216561.

Fey S.J., Larsen P.M., 2001. 2D or not 2D. Current opinion in Chemical Biology 5: 26-33. https://doi.org/10.1002/ ar.23752.

Fraga H.P.F., Vieira L.d.N., Heringer A.S., Puttkammer C.C., Silviera V., Guerra M.P., 2016. DNA methylation and proteome profiles of Araucaria angustifolia (Bertol.) Kuntze embryogenic cultures as affected by plant growth regulators supplementation. Plant Cell Tissue, Organ and Culture 125: 353-374. https://doi. org/10.1007/s11240-016-0956-y.

Fraga H.P.F., Vieira L.d.N., Puttkammer C.C., Oliveira E.M., Guerra M.P., 2015. Time-lapse cell tracking reveals morphohistological features in somatic embryogenesis of Araucaria angustifolia (Bert) O. Kuntze. Trees 29: 1613-1623. https://doi.org/10.1007/ s00468-015-1244-X.

George E.F., Hall M.A., Klerk G.-J.d., 2008. Plant propagation by tissue culture. Springer, Dordrecht, $503 \mathrm{p}$.

Guerra M.P., Steiner N., Farias-Soares F.L., Vieira L.d.N., Fraga H.P.F., Rogge-Renner G.D., Maldonado S., 2016. Somatic embryogenesis in Araucaria angustifolia (Bertol.) Kuntze (Araucariaceae). In: Germanà M.A., Lambardi M. (eds) In vitro embryogenesis in higher plants (Methods in molecular biology). Springer, New York, pp. 439-450.

Gupta P.K., Pullman G.S., 1991. Method for reproducing coniferous plants by somatic embryogenesis using abscisic acid and osmotic potential variation. US patent 5: 36-37.

Haecker A., Gross-Hardt R., Geiges B., Sarkar A., Breuninger H., Herrmann M., Laux T., 2004. Expression dynamics of WOX genes mark cell fate decisions during early embryonic patterning in Arabidopsis thaliana. Development 131: 656-668. https://doi.org/10.1242/ dev.00963.

Hakman I., Fowke L.C., 1987. An embryogenic cell suspension culture of Picea glauca (white spruce). Plant Cell Reports 6: 20-22. https://doi.org/10.1007/ BF00269730.

Hedman H., Zhu T., von Arnold S., Sohlberg J.J., 2013. Analysis of the WUSCHEL-RELATED HOMEOBOX gene family in the conifer Picea abies reveals extensive conservation as well as dynamic patterns. BMC Plant Biology, 13(1): 89. https://doi.org/10.1186/1471-222913-89.

Heldt H.-W., Piechulla B., Heldt F., 2011. Plant Biochemistry, Elsevier, London, p.

Heng Y.-W., Koh C.-G., 2010. Actin cytoskeleton dynamic and the cell division cycle. The International Journal of Biochemistry and Cell Biology 42: 1622-1633. https:// doi.org/10.1016/j.biocel.2010.04.007.

Hussey P.J., Ketelaar T., Deeks M.J., 2006. Control of actin cytoskeleton in plant cell growth. Annuals Review Plant Biology 57: 109-125. https://doi.org/10.1146/ annurev.arplant.57.032905.105206.

Inza M.V., Aguirre N.C., Torales S.L., Pahr N.M., 
Fassola H.E., Fornes L.F., Zelener N., 2018. Genetic variability of Araucaria angustifolia in the Argentinean Parana Forest and implications for management and conservation. Trees 32(4): 1135-1146. https://doi. org/10.1007/s00468-018-1701-4.

Issawi M., Muhieddine M., Girard C., Sol V., Rioul C., 2017. Unexpected features of exponentially growing Tobacco Bright yellow-2 cell suspension culture in relation to excreted extracellular polysaccharides and cell wall composition. Glycoconjugate Journal 34: 585590. https://doi.org/10.1007/s10719-017-9782-7.

IUCN. 2017. The IUCN Red List of Threatened Species. 10.2305/IUCN.UK.2008.RLTS.

Jamet E., Canut H., Boudart G., Pont-Lezica R.F., 2006. Cell wall proteins: a new insight through proteomics. Trends in Plant Science 38: 33-39. https://doi. org/10.1016/j.tplants.2005.11.006.

Jensen W.A., 1962. Botanical histochemistry (principles and pratice). W. H. Freeman and Company, San Francisco, $408 \mathrm{p}$.

Jo L., Dos Santos A.L.W., Bueno C.A., Barbosa H.R., Floh E.S.I., 2014. Proteomic analysis and polyamines, ethylene and reactive oxygen species levels of Araucaria angustifolia (Brazilian pine) embryogenic cultures with different embryogenic potential. Tree Physiology 34: 94-104. https://doi.org/10.1093/t ree phy s/tp $\mathrm{t} 102$.

Johansen D.A., 1940. Plant microtechnique, Mc Graw Hill New York, 523 p.

Knox J.P., 1992. Cell adhesion, cell separation and plant morphogenesis. The Plant Journal 2: 137-141. https:// doi.org/10.1111/j.1365-313X.1992.00137.x.

Kraus J.E., Arduin M., 1997. Manual básico de métodos em morfologia vegetal, Universidade Rural do Rio de Janeiro, Seropédica, 198 p.

Kurakawa T., Ueda N., Maekawa M., Kobayashi K., Kojima M., Nagato Y., Sakakibara H., Kyozuka J., 2007. Direct control of shoot meristem activity by a cytokinin-activating enzyme. Nature 445: 652-655. https://doi.org/10.1038/nature05504.

Kuroha T., Tokunaga H., Kojima M., Ueda N., Ishida T., Nagawa S., Fukuda H., Sugimoto K., Sakakibara H., 2009. Functional analyses of LONELY GUY cytokininactivating enzymes reveal the importance of the direct activation pathway in Arabidopsis. The Plant Cell 21: 3152-3169. https://doi.org/10.1105/tpc.109.068676

Larsson E., Sitbon F., Liung K., von Arnold S., 2008. Inhibited polar auxin transport results in aberrant embryo development in Norway spruce. New Phytologist 177: 365-366. https://doi.org/10.1111/ j.1469-8137.2007.02289.x.

Li X., Han J.-D., Fang S.-N., Bai S.-N., Rao G.-Y., 2017. Embryogenesis-associated genes during somatic embryogenesis of Adiantum capillus-veneris L. in vitro: new insights into the evolution of reproductive organs in land plants. Frontiers in Plant Science 8: 1-13. https:// doi.org/10.3389/fpls.2017.00658.

Lian G., Ding Z., Wang Q., Zhang D., Xu J., 2014. Origins and evolution of WUSCHEL-Related Homeobox protein family in plant kingdom. The Scientific World Journal 2014: 1-12. https://doi.org/10.1155/2014/534140.

Llyod C., Chan J., 2008. The parallel lives of microtubules and cellulose microfibrils. Current opinion in Cell Biology 11: 641-646. https://doi.org/10.1016/j. pbi.2008.10.007.

Lulsdorf M.M., Tautorus T.E., Kikcio S.I., Dunstan D.I., 1992. Growth parameters of embryogenic suspension cultures of interior spruce (Picea glauca-engelmannii) and black spruce (Picea mariana Mill.). Plant Science 82: 227-234. https://doi.org/10.1016/01689452(92)90224-A.

Mathesius U., Keijzers G., Natera S.H.A., Weinman J.J., Djordjevic M.A., Rolfe B.G., 2001. Establishment of a root proteome reference map for the model legume Medicago truncatula using the expressed sequence tag database for peptide mass fingerprinting. Proteomics 1: 1424-1440. https://doi.org/10.1002/1615-9861.

Maurer J.B.B., Bacic A., Pereira-Netto A.B., Donatti L., Zawadzki-Baggio S.F., Pettolino F.A., 2010. Arabinogalactan-proteins from cell suspension cultures of Araucaria angustifolia. Phytochemistry 71: $\quad$ 1400-1409. https://doi.org/10.1016/j. phytochem.2010.04.021.

Mortier V., Wasson A., Jaworek P., Keyser A.d., Decroos M., Holster M., Trakowski P., Mathesius U., Goormachtig S., 2014. Role of LONELY GUY genes in indeterminate nodulation on Medicago truncatula. New Phytologist 202: 582-593. https://doi.org/10.1111/ nph.12681.

Moser J.R., Gonçalves Garcia M., Viana M., 2004. Establishment and growth of embryogenic suspension cultures of Ocotea catharinensis Mez. (Lauraceae). Plant Cell Tissue, Organ and Culture 78: 37-42. https:// doi.org/10.1023/B:TICU.0000020387.96568.25.

Muschitz A., Riou C., Mollet J.-C., GLoaguen V., Faugeron C., 2015. Modifications of cell wall pectin in tomato cell suspension in response to cadmium and zinc. Acta Physiologiae Plantarum 37: 245. https://doi. org/10.1007/s11738-015-2000-y.

Mustafa N., Winter W., Iren F., Verpoorte R., 2011. Initiation, growth and crypreservation of plant cell suspensions cultures. Nature Protocols 6: 715-742. https://doi.org/10.1038/nprot.2010.144.

Oppenheimer D.G., Haas N., Silflow C.D., Snustad D.P., 1988. The beta tubulin gene family of Arubidopsis thaliana: preferential accumulation of the betal transcript in roots. Gene 63: 87-102. https://doi. org/10.1016/0378-1119(88)90548-3.

Palovaara J., Hakman I., 2008. Conifer WOX-related homeodomain transcription factors, developmental consideration and expression dynamic of WOX2 during Picea abies somatic embryogenesis. Plant Molecular Biology 66: 533-549. https://doi.org/10.1007/s11103008-9289-5.

Pieruzzi F.P., Dias L.L.C., Balbuena T.S., Santa-Catarina C., Dos Santos A.L.W., Floh E.S.I., 2011. Polyamines, 
IAA and ABA during germination in two recalcitrant seeds: Araucaria angustifolia (Gymnosperm) and Ocotea odorifera (Angiosperm). Annals of Botany 108: 337-345. https://doi.org/10.1093/aob/mcr133.

Pozo J.C.d., Manzano C., 2014. Auxin and the ubiquitin pathway. Two players-one target: the cell cycle in action. Journal of Experimental Botany 65: 2617-2632. https://doi.org/10.1093/jxb/ert363.

Rabilloud T., Chevallet M., Luche S., Lelong C., 2010. Two-dimensional gel electrophoresis in proteomics: past, present and future. Journal of Proteomics 73: 20642077. https://doi.org/10.1016/j.jprot. 2010.05.016.

Radauer C., Hoffmann-Sommergruber K., 2007. Profilins. In: Mills ENC, Shewry PR (eds) Plant food allergens. Blackwell Publishing, Oxford, pp. 105-124.

Ramagli L.S., Rodriguez L.V., 1985. Quantitation of microgram amounts of protein in twodimensional polyacrylamide gel electrophoresis sample buffer. Electrophoresis 1085: 559-563. https://doi.org/10.1002/ elps. 1150061109.

Reis M.S.d., Montagna T., Mattos A.G., Filippon S., Ladio A.H., Marques A.d.C., Zechini A.A., Peroni N., Mantovani A., 2018. Domesticated landscapes in Araucaria forests, Southern Brazil: A multispecies local conservation-by-use system. Frontiers in Ecology and Evolution 6: 11. https://doi.org/10.3389/ fevo.2018.00011.

Rockenbach M.F., Boneti J.I., Cangahuala-Inocente G.C., Gavioli-Nascimento M.C.A., Guerra M.P., 2015. Histological and proteomics analysis of apple defense responses to the development of Colletotrichum gloeosporioides on leaves. Physiological and Molecular Plant Pathology 89: 97-107. https://doi.org/10.1016/j. pmpp. 2015.01.003.

Rogowska-Wrzesinska A., Bihan M.-C.L., ThaysenAndersen M., Roepstorff P., 2013. 2D gels still have a niche in proteomics. Journal of Plant Proteomics 88: 4-13. https://doi.org/10.1016/j.jprot.2013.01.010.

Salmen Espindola L., Noin M., Corbineau F., Côme D., 1994. Cellular and metabolic damage induced by desiccation in recalcitrant Araucaria angustifolia embryos. Seed Science Research 4: 1993-1201. https:// doi.org/10.1017/S096025850000218X.

Santer A., Estelle M., 2009. Recent advances and emerging trends in plant hormone signalling. Nature 459: 10711078. https://doi.org/10.1038/ nature08122.

Sass J.E., 1951. Botanical microtechnique. Iowa State College, Ames, 228 p.

Shi H.-Y., Zhang Y.-X., Chen L., 2013. Two pear auxinrepressed protein genes, PpARP1 and PpARP2, are predominantly expressed in fruit and involved in response to salicylic acid signaling. Plant Cell Tissue, Organ and Culture 114: 279-286. https://doi. org/10.1007/ s11240-013-0321-3.

Silveira V., Balbuena T.S., Santa-Catarina C., Floh E.S.I., Guerra M.P., Handro W., 2004. Biochemical changes during seed development in Pinus taeda L. Plant Growth Regulation 44: 147-156. https:/doi. org/10.1007/s10725-004-2601-8

Silveira V., Steiner N., Dos Santos A.L.W., Nodari R.O., Guerra M.P., 2002. Biotechnology tolls in Araucaria angustifolia conservation and improvement: inductive factors affecting somatic embryogenesis. Crop Breeding and Applied Biotechnology 2: 463-470. https://doi. org/10.12702/1984-7033.v02n03a18

Somers D.E., Fujiwara S., 2009. Thinking outside the F-box: novel ligands for novel receptors. Trends in Plant Science 14: 206-213. https://doi.org/10.1016/j. tplants.2009.01.003

Stasolla C., Yeung E.C., 2003. Recent advances in conifer somatic embryogenesis: improving somatic embryo quality. Plant Cell, Tissue Organ and Culture 73: 15-35. https://doi.org/10.1023/A: 1023345803336.

Stefenon V.M., Gailing O., Finkeldey R., 2007. Genetic structure of Araucaria angustifolia (Araucariaceae) populations in Brazil: implications for the in situ conservation of genetic resources. Plant Biology 9: 516525. https://doi.org/10.1055/s-2007-964974.

Steiner N., Farias-Soares F.L., Schmidt E.C., Pereira M.L.T., Scheid B., Rogge-Renner G.D., Bouzon Z.L., Schmidt D., Maldonado S., Guerra M.P., 2015. Toward establishing a morphological and ultrastructural characterization of proembryogenic masses and early somatic embryos of Araucaria angustifolia (Bert.) O. Kuntze. Protoplasma 253(2), 487-501. https://doi. org/10.1007/ s00709-015-0827-0.

Steiner N., Santa-Catarina C., Andrade J.B.R., Balbuena T.S., Guerra M.P., Handro W., Floh E.S.I., Silveira V., 2008. Araucaria angustifolia biotechnology. Functional Plant Science and Biotechnology 2: 20-28. https://doi. org/10.1590/S1516-89132002000100015

Steiner N., Santa-Catarina C., Guerra M.P., Cutri L., Dornelas M., Floh E.S.I., 2012. A gymnosperm homolog of SOMATIC EMBRYOGENESIS RECEPTOR-LIKE KINASE-1 (SERK1) is expressed during somatic embryogenesis. Plant Cell Tissue, Organ and Culture 109: 41-50. https://doi.org/10.1007/s11240-011-0071-z.

Steiner N., Santa-Catarina C., Silveira V., Floh E.S.I., Guerra M.P., 2007. Polyamine effects on growth and endogenous hormones levels in Araucaria angustifolia embryogenic cultures. Plant Cell Tissue, Organ and Culture 89: 55-62.

Steiner N., Vieira F.d.N., Maldonado S., Guerra M.P., 2005. Effect of carbon source on morphology and histodifferentiation of Araucaria angustifolia embryogenic cultures. Brazilian Archives of Biology and Technology 48: 895-903. https://doi.org/10.1590/ S1516-89132005000800005.

Steward F.C., Mapes M.O., Mears K., 1958. Growth and organized development of cultured cells II. Organization in cultures grown from freely suspended cells. American Journal of Botany 45: 705-708. https:// doi.org/10.1002/j.1537-2197.1958.tb10599.x.

Straeten D.V.D., Pousada-Rodrigues R.A., Goodman H.M., Montagu M.V., 1991. Plant enolase: gene structure, expression and evolution. The Plant Cell 3: 
719-735. https://doi.org/10.1105/tpc.3.7.719.

Szabados L., Mroginski L.A., Roca W.M., 1993. Suspensiones celulares: descripción, manipulación y aplicaciones. In: Roca W.M., Mroginski L.A. (eds) Cultivo de tejidos en la agricultura: fundamentos y aplicaciones. CIAT, Cali, pp. 174-210.

Vogel G., 2005. How does a single somatic cell become a whole plant? Science 309: 86. https://doi.org/10.1126/ science.309.5731.86.

Von Arnold S., 2008. Somatic embryogenesis. In: George E.F., Hall M.A., Klerk G.-Jd. (eds) Plant propagation by tissue culture, 3 rd. edn. Springer, Dordrecht, pp. 335-358.

Von Arnold S., Egertsdotter U., Ekberg I., Gupta P.K., Newton R.J., 1995. Somatic embryogenesis in Norway spruce (Picea abies). In: Jain S.M., Gupta P.K., Newton R.J. (eds) Somatic embryogenesis in woody plants. Springer Netherlands, Dordrchet, pp. 44-46.
Von Arnold S., Sabala I., Bozhkov P.V., Dyachok J., Filanova L.H., 2002. Developmental pathways of somatic embryogenesis. Plant Cell, Tissue Organ and Culture 69: 233-249. https://doi.org/10.1023/A: 1015673200621 .

Van der Graaff E.v.d., Laux T., Rensing S.A., 2009. The WUS homeobox-containing (WOX) protein family. Genome Biology 10(12): 248. https://doi.org/10.1186/ gb-2009-10-12-248.

Webster J.M., Oxley D., Pettolino F.A., Bacic A., 2008. Characterisation of secreted polysaccharides and (glyco)proteins from suspension cultures of Pyrus communis. Phytochemistry 69: 873-881. https://doi. org/10.1016/j.phytochem.2007.10.009.

Wink M., 1994. The cell culture medium - a functional extracellular compartment of suspension-cultured cells. Plant Cell Tissue, Organ and Culture 38: 307-319. https://doi.org/10.1007/BF00033891. 